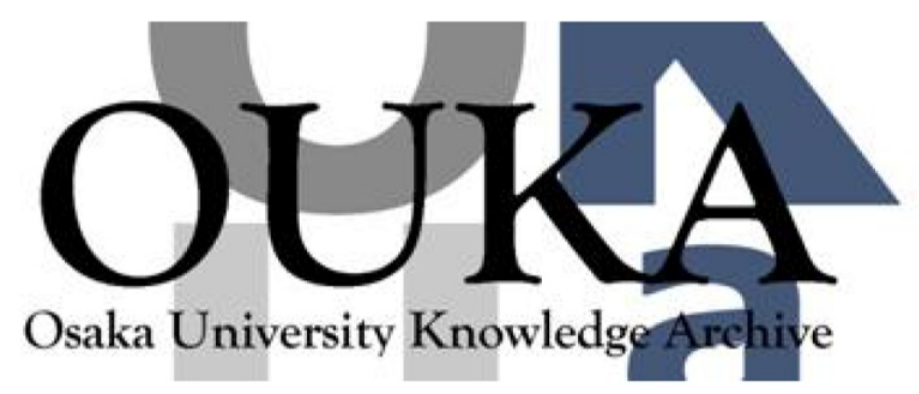

\begin{tabular}{|c|l|}
\hline Title & $\begin{array}{l}\text { PATERNO-BÜCHI REACTION OF ACID ANHYDRIDE } \\
\text { OXETANES FROM GLUTARIC ANHYDRIDE }\end{array}$ \\
\hline Author(s) & Maruyama, Kazuhiro; Ogawa, Takuj i; Kubo, Yasuo \\
\hline Citation & CHEMISTRY LETTERS. 9(3) p.343-p.344 \\
\hline Issue Date & 1980 \\
\hline oaire:version & VoR \\
\hline URL & https://hdl. handle. net/11094/3010 \\
\hline rights & \\
\hline Note & \\
\hline
\end{tabular}

Osaka University Knowledge Archive : OUKA

https://ir. Library. osaka-u. ac. jp/

Osaka University 


\title{
PATERNO-BÜCHI REACTION OF ACID ANHYDRIDE OXETANES FROM GLUTARIC ANHYDRIDE
}

\author{
Kazuhiro MARUYAMA, Takuji OGAWA, and Yasuo KUBO \\ Department of Chemistry, Faculty of Science,
}

Kyoto University, Kyoto 606

\begin{abstract}
Glutaric anhydride underwent the Paterno-Büchi reaction with olefins and gave oxetanes in good yields. The quantum yield was 0.16 . Acetic anhydride didn't undergo this reaction contrarily.
\end{abstract}

It has been established that simple carbonyl compounds, ketones and aldehydes, undergo the Paterno-Büchi reaction with olefins. However, examples of the reaction involving carboxylic acid derivatives as the carbonyl component are not so common. Previously we reported that N-methyl-glutarimide underwent the Paterno-Büchi reaction with a series of olefins to give oxetanes. ${ }^{1)}$ We extended the reaction to carboxylic anhydrides, which can be regarded as more principal acid derivatives. Carboxylic anhydrides similarly reacted with olefins to give oxetanes upon irradiation. As for the photochemical reaction of acid anhydride, only $\alpha$-cleavage reactions have been reported. ${ }^{2}$ ) This is the first report of the Paterno-Büchi reaction of acid anhydrides.

Typically an acetonitrile solution of glutaric anhydride (0.175M) la and excess isobutene (ca. 1.3M) 2a was placed in a quartz vessel and irradiated with 120W low pressure Hg-lamp. After irradiation for about $240 \mathrm{~h}$, when almost all glutaric anhydride was consumed, excess isobutene and solvent were removed. Distillation of the brown residue by a Kugelrohr gave colorless oil in a yield of 67\%, which was determined to be a mixture of oxetane isomers $3 \mathrm{a}$ and $4 \mathrm{a}$ based on the spectral data. $\quad{ }^{1} \mathrm{H} \operatorname{NMR}\left(\mathrm{CCl}_{4}\right) \delta 1.27(\mathrm{~s}, 3 \mathrm{H}, \mathrm{Me}), 1.30(\mathrm{~s}, 3 \mathrm{H}, \mathrm{Me}), 1.6-3.0(\mathrm{~m}, 6 \mathrm{H}$, methylene), 3.97 and $4.31\left(\mathrm{ABq}, \mathrm{J}=6 \mathrm{~Hz}, 2 \mathrm{H}, \mathrm{OCH}_{2}\right) ; \mathrm{IR}$ (neat) $1744,932 \mathrm{~cm}^{-1}$; MS $(20 \mathrm{eV}) \mathrm{m} / \mathrm{e}$ (rel. intensity) $170\left(\mathrm{M}^{+}, 18\right), 140$ (91), 98 (100), 97 (100) ; elemental analysis, required C 63.51\%, H 8.29\%, found C 63.76\%, H 8.39\%. Isomeric oxetanes $\stackrel{3}{\sim}$ and $\underset{4}{\sim}$ can be distinguished by their ${ }^{1} \mathrm{H}$ NMR spectra of the mixture and the ratio of them (3/4) is about 7 estimated from the ${ }^{1}{ }_{H}$ NMR signal area of methyl groups on oxetane ring. Other examples are summarized in Table.

The quantum yield of oxetane formation was determined to be 0.16 , using 1 a $0.1 \mathrm{M}$ and $2 \mathrm{~b} 1.2 \mathrm{M}$. This reaction was suppressed in the presence of about $0.7 \mathrm{M}$ butadiene, and the isomer 3 produced via more stable biradical intermediate was major. Therefore, it seems reasonable to conclude that this reaction occurs from the $n \pi$ * triplet state of acid anhydride.

Under similar conditions photochemical reactions of acetic anhyäride and N-methyl-acetylimide with olefins were also examined, but none of them succeeded to react. Extinction coefficient of acetic anhydride (loge l.3 at $\left.254 \mathrm{~nm}^{3}\right)$ ) is comparable to that of glutaric anhydride (loge l.2 at $\left.254 \mathrm{~nm}^{4}\right)$ ). We think the difference of photochemical behavior between open chain compounds (acetic anhydride and N-methyl-acetylimide) and cyclic compounds (glutaric anhydride and N-methylglutarimide) may be due to the differences of their triplet life time. Open chain 
<smiles>[R]C(=O)OCCO</smiles>

$\stackrel{1}{2}$



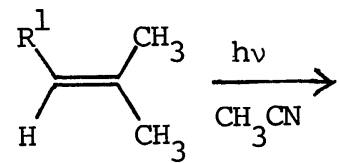

$\stackrel{2}{\sim}$

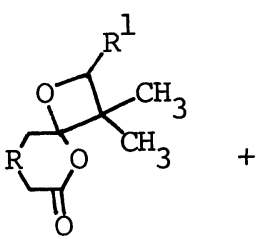

$\stackrel{3}{\sim}$

Table

\begin{tabular}{|c|c|}
\hline Products ${ }^{\text {) }}$ & Yield $\left(\frac{\circ}{b}\right)^{a)}$ \\
\hline $3 a, 4 a$ & 67 \\
\hline $3 b, 4 b$ & 54 \\
\hline$\underset{3 c}{\sim}, \underline{c}$ & 59 \\
\hline$\stackrel{3 d}{\sim}, \underset{\sim}{4 d}$ & 61 \\
\hline 3e,$\underset{\sim}{\sim}$ & 62 \\
\hline $3 f ， \underset{\sim f}{\sim}$ & 70 \\
\hline
\end{tabular}<smiles>[R]C1OC2(CC(=O)O2)C1(C)C</smiles>

$\stackrel{4}{\sim}$

$$
\begin{aligned}
& \left.\mathrm{b} \cdot \mathrm{p} \cdot\left({ }^{\circ} \mathrm{C} / \text { torr }\right)^{\mathrm{b}}\right) \\
& 90-95 / 0.03 \\
& 93-96 / 0.03 \\
& 80-85 / 0.01 \\
& 80-85 / 0.01 \\
& 98-105 / 0.02 \\
& 102-110 / 0.02
\end{aligned}
$$

a) Isolated yield

b) Kugelrohr

compounds are apt to be more easily deactivated than cyclic compounds because of the larger freedom on molecular movement. ${ }^{5)}$

Succinic anhydride also undergo the Paterno-Büchi reaction, but the rate of the reaction was rather slower than glutaric anhydride and the anhydride cannot convert to the oxetane perfectly. Small extinction coefficient (loge 0.1 at 254nm $\left.{ }^{6}\right)$ may reflect this slow conversion rate.

References and Notes

1) a) K. Maruyama and Y. Kubo, J. Org. Chem., 42, 3215 (1977).

b) K. Maruyama, T. Ogawa, and Y. Kubo, Chem. Lett., 1978, 1107.

2) a) G. A. Chamberlain, and E. Whittle, J. Chem. Soc., Faraday Trans. 1, 1978 (1975).

b) H. Hiraoka, J. Am. Chem. Soc., 95, 1664 (1973).

c) A. A. M. Roof, H. F. van woerden, and H. Cerforitain, Tetrahedron Lett., $1975,815$.

d) A. A. M. Roof, H. F. van Woerden, and H. Cerfontain, Tetrahedron, 32, 2967 (1976).

3) H. Ley and B.Arends, Z. Physik. Chem., 17B, 195 (1932).

4) Our measurement.

5) a) C. D. deBoer, and R. H. Schlessinger, J. Am. Chem. Soc., 90, 803 (1968).

b) J. Saltiel, O. C. Zafirious, E. D. Megarity, and A. A. Lamola, J. Am. Chem. Soc., $\underline{90}, 4759$ (1968).

6) J. Shurtz, E. Treiber, and H. Toplak, Z. Electrochemie, 60, 68 (1956).

7) The ratios are about 7 . 